\title{
Effect of concentrate feeding level on methane emissions, production performance and rumen fermentation of Jersey cows grazing ryegrass pasture during spring
}

\author{
J.D.V. van Wyngaard ${ }^{\mathrm{a},{ }^{*}}$, R. Meeske ${ }^{\mathrm{b}}$, L.J. Erasmus ${ }^{\mathrm{a}}$ \\ ${ }^{a}$ Department of Animal and Wildlife Sciences, University of Pretoria, Private Bag X20, Hatfield \\ 0028, South Africa \\ ${ }^{b}$ Department of Agriculture, Western Cape, Outeniqua Research Farm, P. O. Box 249, George \\ 6530, South Africa
}

*Corresponding author. Tel.: +27 44803 3700; mobile: +27 82336 0626; fax: +27 44874 7730; e-mail address: jdvvanwyngaard@gmail.com or josefvw@elsenburg.com

Submitted to Animal Feed Science and Technology in January 2018

\section{Highlights}

- Concentrate feeding level as methane mitigation strategy for grazing dairy cows.

- Milk yield and dry matter intake increased with increasing concentrate level.

- Pasture intake and milk fat content decreased with increasing concentrate level.

- Only minor effects on ruminal fermentation were observed.

- Methane per milk yield (g/kg) decreased linearly with increasing concentrate level. 


\section{Abstract}

Dietary supplementation has been well documented as an effective enteric methane $\left(\mathrm{CH}_{4}\right)$ mitigation strategy. However, limited studies have demonstrated the effect of concentrate level on enteric $\mathrm{CH}_{4}$ emissions from grazing dairy cows, and to our knowledge none of these studies included a pasture-only diet or reported on rumen fermentation measures. Sixty multiparous (4.0 $\pm 1.51 \mathrm{SD})$ Jersey cows, of which six were rumen-cannulated, were used in a randomised complete block design, and the cannulated cows were used in a separate replicated $3 \times 3$ Latin square design, to investigate the effect of concentrate supplementation $(0,4$, and $8 \mathrm{~kg} / \mathrm{cow}$ per day; as fed $)$ on enteric $\mathrm{CH}_{4}$ emissions, milk production, dry matter intake (DMI), and rumen fermentation of dairy cows grazing perennial ryegrass pasture during spring, following a 14-d adaptation period. The sulphur hexafluoride tracer gas technique was used to measure enteric $\mathrm{CH}_{4}$ emissions from 10 cows of each treatment group over a single 9-d measurement period. Parallel with the $\mathrm{CH}_{4}$ measurement period, pasture DMI was determined using $\mathrm{TiO}_{2}$ and indigestible neutral detergent fibre as external and internal markers, respectively, while milk yield, milk composition, cow condition, and pasture pre- and post-grazing measurements were also recorded. Total DMI (13.4 to 18.0 $\mathrm{kg} / \mathrm{d}$ ), milk yield (12.9 to $19.2 \mathrm{~kg} / \mathrm{d}$ ), energy corrected milk (14.6 to $20.7 \mathrm{~kg} / \mathrm{d}$ ), milk lactose content (46.2 to $48.1 \mathrm{~g} / \mathrm{kg}$ ) and gross energy intake (239 to $316 \mathrm{MJ} / \mathrm{d}$ ) increased, while milk fat content (50.0 to $44.2 \mathrm{~g} / \mathrm{kg}$ ) decreased with increasing concentrate feeding level. Volatile fatty acid concentrations and ruminal $\mathrm{pH}$ were mostly unaffected by treatment, while dry matter disappearance decreased and $\mathrm{NH}_{3}-\mathrm{N}$ concentration increased with increasing concentrate feeding level. Methane production (258 to $302 \mathrm{~g} / \mathrm{d}$ ) and $\mathrm{CH}_{4}$ yield (20.6 to 16.9 $\mathrm{g} / \mathrm{kg}$ of DMI) were similar for all cows, while pasture DMI (13.4 to $10.8 \mathrm{~kg} / \mathrm{d})$ and $\mathrm{CH}_{4}$ intensity (20.4 to $15.9 \mathrm{~g}$ of $\mathrm{CH}_{4} / \mathrm{kg}$ of milk yield) decreased linearly with increasing concentrate feeding level. Results indicate that concentrate supplementation on high quality 
pasture-only diets have the potential to effectively reduce $\mathrm{CH}_{4}$ emissions per unit of milk yield from grazing cows during spring.

Keywords: $\mathrm{CH}_{4}$ measurement; perennial ryegrass; methane mitigation; pasture-based; $\mathrm{SF}_{6}$

Abbreviations: $\mathrm{BCS}$, body condition score; $\mathrm{CH}_{4}$, methane; $\mathrm{CP}$, crude protein; DIM, days in milk; DM, dry matter; DMI, dry matter intake; ECM, energy corrected milk; FCM, fat corrected milk; FO, faecal output; GE, gross energy; iNDF, indigestible neutral detergent fibre; ME, metabolisable energy; MUN, milk urea nitrogen; NDF, neutral detergent fibre; NIWA, National Institute of Water and Atmosphere; OMD, in vitro organic matter digestibility; $\mathrm{SCC}$, somatic cell count; $\mathrm{SF}_{6}$, sulphur hexafluoride; VFA, volatile fatty acid

\section{Introduction}

Over the past decade, enhanced management and genetics in dairy farming have resulted in increased milk production which led to, inter alia, improved feed efficiency and a more cost-effective product (Negussie et al., 2017). Conversely, dairy farming results in emissions of methane $\left(\mathrm{CH}_{4}\right)$ gas that is mainly produced by microbes in the rumen. Methane is a damaging greenhouse gas with 28 times the greenhouse potential of carbon dioxide over a 100 year period (Myhre et al., 2013) and signifies a loss of energy that could have been converted into animal products. The livestock sector is a major contributor to the buildup of $\mathrm{CH}_{4}$ emissions in the atmosphere. The South African cattle industry produced $964 \mathrm{Gg}$ of $\mathrm{CH}_{4}$ emissions during 2010 , of which $13.5 \%$ was represented by the dairy sector mainly in the form of enteric $\mathrm{CH}_{4}$ emissions (Du Toit et al., 2013). The latter statistics were obtained by means of Tier 2 methodologies as described by the IPCC (2006). The need to implement a more refined method, such as Tier 3 methodologies, to further improve the accuracy of current national greenhouse gas inventories as well as the need to alleviate enteric $\mathrm{CH}_{4}$ emissions has become a growing concern on an international level. 
Several effective mitigation strategies for enteric $\mathrm{CH}_{4}$ emissions have been extensively reviewed (Hristov et al., 2013; Knapp et al., 2014), which can be classified in the following categories: feeds and nutrition, rumen modifiers, and herd management and genetics. When selecting a mitigation strategy the combined effects of whole-farm profitability, on-farm practicality, and adoption potential should be considered (Hristov et al., 2013). Feeding high levels of concentrates as mitigation strategy meets the latter conditions. Tyrrell and Moe (1972) showed that $\mathrm{CH}_{4}$ yield (g/kg of dry matter intake (DMI)) and intensity (g/kg of animal production) will decrease by increasing the proportion of concentrate in the diet if animal production remains the same or is increased. However, although concentrate feeding level has been evaluated extensively as a $\mathrm{CH}_{4}$ mitigation strategy in confined dairy systems (Yan et al., 2010; Aguerre et al., 2011), pasture-based dairy systems received much less attention. The limited work undertaken has generally indicated that milk production and total DMI increased with increasing concentrate level, whereas the $\mathrm{CH}_{4}$ emission response to treatment varied, with one study showing no treatment response (Young and Ferris, 2011). The level of concentrate evaluated in these limited studies ranged from 1 to $8 \mathrm{~kg} / \mathrm{cow}$ per day and cows mainly grazed perennial ryegrass (Lolium perenne) dominant pasture during spring.

To our knowledge, no grazing study to date has examined the effect of concentrate level on enteric $\mathrm{CH}_{4}$ emissions with the inclusion of a pasture-only treatment. Furthermore, although the potential of rumen parameters such as volatile fatty acids (VFA) and pH to act as proxies for enteric $\mathrm{CH}_{4}$ emissions is variable (Negussie et al., 2017), $\mathrm{CH}_{4}$ emissions studies that include these rumen fermentation measurements can be beneficial for future $\mathrm{CH}_{4}$ proxy meta-analysis studies.

Thus, the aim of the study was to determine the effect of different concentrate levels (including a pasture-only treatment) on $\mathrm{CH}_{4}$ emissions, production performance and rumen fermentation of Jersey cows grazing perennial ryegrass pasture during spring. We 
hypothesised that an increased concentrate level will increase milk production and total DMI while decreasing $\mathrm{CH}_{4}$ yield and intensity. We further hypothesised that enteric $\mathrm{CH}_{4}$ emissions will increase as total DMI increases. Results obtained from this study can be used to improve the accuracy of the greenhouse gas inventory of the pasture-based South African dairy sector, and may have application to grazing based dairy sectors in other countries.

\section{Materials and methods}

\subsection{Location description}

The study was conducted during spring of 2015 (September - November) at the

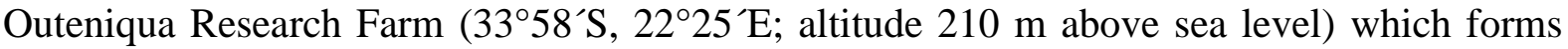
part of the Western Cape Department of Agriculture (Elsenburg, South Africa). The study area has a temperate climate with a long-term (45 years) mean annual precipitation of 732 $\mathrm{mm}$, distributed throughout the year, and a mean daily maximum and minimum temperature range of $18^{\circ} \mathrm{C}$ to $25^{\circ} \mathrm{C}$, and $7^{\circ} \mathrm{C}$ to $15^{\circ} \mathrm{C}$, respectively. Ethical clearance for animal care and use was obtained from the Western Cape Department of Agriculture (Elsenburg, South Africa) before commencement of the study (DECRA approval number: R114/115).

\subsection{Animals, experimental design and treatments}

Sixty multiparous Jersey cows (six rumen-cannulated) with mean pre-experimental milk yield of $20.1( \pm 2.29$ SD) $\mathrm{kg} / \mathrm{d}, 142( \pm 52 \mathrm{SD})$ days in milk (DIM), mean parity of 4.0 $( \pm 1.51 \mathrm{SD})$, and mean body weight of $398( \pm 33.2 \mathrm{SD}) \mathrm{kg}$ were selected from the Outeniqua dairy herd. Intact cows (54) formed part of a production study and were blocked (18 blocks) according to pre-experimental milk yield, DIM, and parity in one of three treatment groups. Each treatment group was then randomly assigned to one of three treatments that differed by level of concentrate feeding: 0,4 and $8 \mathrm{~kg} / \mathrm{cow}$ per day (as fed basis). Furthermore, the six rumen-cannulated cows (previously fitted with Bar Diamond \#1C rumen cannulae; Bar 
Diamond Inc, Idaho, USA) formed part of a separate rumen study with a duplicated $3 \times 3$ Latin square design, which ran concurrent with the production study. Each of the rumencannulated cows was subjected to the three treatments over 20 -d periods (14 d adaptation and 6 d data collection). Concentrate was fed individually to cows in pellet form split in two equal portions during milking. The ingredient composition of the concentrate offered was as follows (g/kg of dry matter; DM): 695 ground maize, 116 soybean oilcake, 34 sugarcane molasses, 20 limestone $\left(\mathrm{CaCO}_{3}\right), 3.7$ monocalcium phosphate, 5.6 salt, 3.1 magnesium oxide and 1 trace mineral and vitamin premix (containing $4 \mathrm{mg}$ of $\mathrm{Cu} / \mathrm{kg}, 10 \mathrm{mg}$ of $\mathrm{Mn} / \mathrm{kg}, 20 \mathrm{mg}$ of $\mathrm{Zn} / \mathrm{kg}, 0.34 \mathrm{mg}$ of $\mathrm{I} / \mathrm{kg}, 0.2 \mathrm{mg}$ of $\mathrm{Co} / \mathrm{kg}, 0.06 \mathrm{mg}$ of Se/kg, $6 \times 10^{6} \mathrm{IU}$ of vitamin $\mathrm{A} / \mathrm{kg}, 1$ $\times 10^{6} \mathrm{IU}$ of vitamin D3/kg, and $8 \times 10^{3} \mathrm{IU}$ of vitamin $\mathrm{E} / \mathrm{kg}$ ). Cows were allowed a $14-\mathrm{d}$ dietary adaptation period, followed by a 52-d data collection period that commenced September 4 and ended October 26.

\subsection{Pasture and grazing management}

The experimental paddock (8.55 ha) was under permanent irrigation. The pasture consisted of perennial ryegrass (Lolium perenne L) (69\%), kikuyu (Pennisetum clandestinum) (6\%), white clover (Trifolium repens; 8\%), other grass (Lolium multiflorum and Paspalum dilatatum; 16\%), and broad-leaf weeds (1\%). The soil type was characterised as a Podzol soil type (Swanepoel et al., 2013). The paddock was divided into strips (150 m x $15 \mathrm{~m}$ ) which were top-dressed after each grazing with $42 \mathrm{~kg}$ of nitrogen/ha using limestone ammonium nitrate (containing $280 \mathrm{~g}$ of nitrogen $/ \mathrm{kg}$ ). Cows were held back after milking to allow simultaneous access to fresh pasture as one group, which was allocated twice daily after milking with grazing areas being back-fenced. A strict daily herbage allowance was implemented and was continuously adjusted throughout the study period, to ensure a target post-grazing height of $5.5 \mathrm{~cm}$ above ground level. This was attained by measuring pre- and post-grazing pasture height with a rising plate meter (Jenquip folding plate pasture meter; 
Jenquip, Feilding, NZ) by taking 100 readings in a zigzag pattern across the grazing area. Pasture yield above ground (pre- and post-grazing) were estimated using the following site and season specific linear regression equation: Pasture yield $(\mathrm{kg}$ of DM/ha $)=[120 \times$ pasture height (rising plate meter reading)] $-898\left(\mathrm{R}^{2}=0.75\right)$. Rising plate meter reading is defined in $0.5 \mathrm{~cm}$ units.

\subsection{Measurements}

\subsubsection{Animal performance}

Cows were milked twice daily (0530 and 1330 h) using a 20-point swing-over milking machine, and milk yield was automatically recorded with weigh-all electronic milk (Dairymaster, Causeway, Co. Kerry, Ireland). Milk fat, milk protein, milk lactose and milk urea nitrogen (MUN) were determined from composite a.m. and p.m. milk samples using a Milkoscan FT+ milk analyzer (FOSS Analytical, DK-3400 Hillerød, Denmark), while somatic cell count (SCC) was determined using a Fossomatic FC (FOSS Analytical). Energy corrected milk was calculated using the equations of Tyrrell and Reid (1965): ECM = milk yield $(\mathrm{kg} / \mathrm{d}) \times[$ milk energy content $(\mathrm{MJ} / \mathrm{kg})] / 3.1$; where, milk energy content $(\mathrm{MJ} / \mathrm{kg})=$ $[0.0384 \times$ milk fat $(\mathrm{g} / \mathrm{kg})]+[0.0223 \times$ milk protein $(\mathrm{g} / \mathrm{kg})]+[0.0199 \times$ milk lactose $(\mathrm{g} / \mathrm{kg})]-$ 0.108. Fat-corrected milk (FCM), standarised at $4 \%$ milk fat content, was calculated using the equation of Gaines (1928): $\mathrm{FCM}=[0.4 \times$ milk yield $(\mathrm{kg} / \mathrm{d})]+[15 \times$ milk fat $(\mathrm{kg} / \mathrm{d})]$. Milk data from the rumen-cannulated cows were excluded from the treatment group mean due to the experimental design.

Cow body weight and body condition score (BCS) were recorded, before afternoon milking, at the start and the end of the study. Body weight was electronically recorded over two consecutive days using a fixed weighing scale (Tru-Test EziWeigh v. 1.0 scale, $0.5 \mathrm{~kg}$ accuracy, Auckland, New Zealand) and BCS was determined using the 1 to 5 scale scoring system of Wildman et al. (1982). 


\subsubsection{Dry matter intake}

Individual pasture DMI was estimated with the use of titanium dioxide $\left(\mathrm{TiO}_{2}\right)$ as an external marker to determine faecal output (FO) and indigestible neutral detergent fibre (iNDF) as an internal marker to determine forage digestibility. Ten cows (block 1 to 10) per treatment group were each dosed with $3 \mathrm{~g}$ of $\mathrm{TiO}_{2}$ twice daily over the last 10 days of the experiment, with faecal samples collected twice daily over the last six days of the experiment (Pinares-Patiño et al., 2008). One additional cow per treatment was included for background $\mathrm{TiO}_{2}$ analysis. Faecal samples were immediately oven dried $\left(65^{\circ} \mathrm{C}, 72 \mathrm{~h}\right)$, pooled withinanimal, milled to pass a $1 \mathrm{~mm}$ sieve, and analysed for $\mathrm{TiO}_{2}$ concentration by the method of Myers et al. (2004). Faecal output was calculated from the daily $\mathrm{TiO}_{2}$ dose and $\mathrm{TiO}_{2}$ concentration in faeces according to de Souza et al. (2015).

Representative pasture samples were cut (approximately $3 \mathrm{~cm}$ aboveground level) daily during the DMI measurement period on the successive grazing-strips. Pasture samples were immediately oven dried $\left(55^{\circ} \mathrm{C}, 72 \mathrm{~h}\right)$, pooled and milled to pass a $1 \mathrm{~mm}$ sieve. Concentrate, pasture and faecal samples were incubated in situ for $288 \mathrm{~h}$ in polyester bags (07-11/5 Sefar Petex cloth, Sefar AG, Heiden, Switserland) to determine iNDF (Krizsan et al., 2015). After incubation, neutral detergent fibre (NDF) concentration was determined according to Robertson and van Soest (1981) using an Ankom ${ }^{2000}$ fiber analyser (Ankom Technology Corp., Fairport, NY) assayed with a heat-stable $\alpha$-amylase (protein enzyme EC 3.2.1.1; 1,4- $\alpha$ D-glucan glucanohydrolase) and anhydrous sodium sulfite, and expressed inclusive of residual ash. Pasture DMI was calculated using the equation of Cabral et al. (2014): Pasture DMI $(\mathrm{kg} / \mathrm{d})=[[\mathrm{FO}(\mathrm{kg} / \mathrm{d}) \times$ iNDF faeces $(\mathrm{kg} / \mathrm{kg})]-$ iNDF concentrate intake $(\mathrm{kg} / \mathrm{d})] / \mathrm{iNDF}$ forage $(\mathrm{kg} / \mathrm{kg})$. 


\subsubsection{Enteric methane}

Methane emissions from individual cows were measured using the sulphur hexafluoride tracer gas $\left(\mathrm{SF}_{6}\right)$ technique as described by O'Neill et al. (2011) for grazing dairy cows. This measurement was done concurrently with the faecal collection period of the DMI measurement using the same 30 cows. The $\mathrm{CH}_{4}$ measurement period was over a maximum of nine consecutive days to enable collection of five samples representative of the complete daily emissions of gas from each cow. Empty permeation tubes (P\&T Precision Engineering Ltd., Unit 2, Naas Industrial Estate, Naas, Co. Kildare, W91 KA4C, Ireland) were loaded with $3.0( \pm 0.19 \mathrm{SD}) \mathrm{g}$ of $\mathrm{SF}_{6}$ gas during August 2015. The mean release rate of the permeation tubes was $6.43( \pm 0.40 \mathrm{SD}) \mathrm{mg}$ of $\mathrm{SF}_{6} / \mathrm{d}$ and ranged from 5.48 to $7.07 \mathrm{mg}$ of $\mathrm{SF}_{6} / \mathrm{d}$ one week prior dosing. This was obtained by calibrating the filled tubes in a dry incubator (Labcon Incubator Model FS1M8, Ferndale, Johannesburg) set at $39.0^{\circ} \mathrm{C}$ for five weeks, weighing the tubes (Sartorius BP210S, Sartorius AG, Goettingen, Germany; $0.0001 \mathrm{~g}$ accuracy) every third morning to produce an 11-point regression curve $\left(R^{2}>0.9995\right)$. The permeation tubes were blocked by release rate and randomly allocated to both experimental treatment and cow within treatment. Tubes were individually placed in a size 10 gelatin capsule (Torpac Inc., 333 Route 46, Fairfield, NJ 07004, USA) and dosed per os 7 d prior to the measurement period using a plastic capsule-dose-applicator.

Eructed gasses were continuously sampled over a 24-h period in cylindrical, backmounted polyvinyl chloride (PVC) gas-collection canisters of $1700 \mathrm{~mL}$ with an initial sampling rate of approximately $0.54 \mathrm{~mL} / \mathrm{min}$. This sampling rate allowed for the evacuated canister to fill to approximately $45 \%$ over a $24 \mathrm{~h}$ sampling period. Canisters were mounted on the back of the cows with the technique of van Wyngaard et al. (2018), but without the bespoke shaping shaft. The current study supported the development of the back-mounted harness as described by van Wyngaard et al. (2018). Canisters were reused after flushing 
residue gas by evacuating to $98 \mathrm{kPa}$ vacuum, filling with ultra-high purity nitrogen gas $(999.99 \mathrm{~g} / \mathrm{kg})$ and evacuating again to $98 \mathrm{kPa}$ vacuum, repeated five times. Stainless-steel capillary tubes (1/16"' OD x 0.2'” ID; YY-RES-21503; LECO Co., Saint Joseph, MI 49085, USA) cut to $50 \mathrm{~mm}$ length and crimped using a table top vice-grip were used as flow restrictors.

Four field canisters were used to sample background (ambient) concentrations of $\mathrm{SF}_{6}$ and $\mathrm{CH}_{4}$. These background canisters were hung on the fence along each side of the grazing area where the cows were allocated. Background canisters were replaced every $24 \mathrm{~h}$ with evacuated canisters during the $\mathrm{CH}_{4}$ measurement period. Only background canisters were used for this exercise and not sample canisters. Background gas concentrations from all canisters were averaged per day to give a single estimate for all experimental cows.

A piston sub-sampler (National Institute of Water and Atmosphere (NIWA) Ltd., Viaduct Harbour, Auckland Central, 1010, NZ) was used to extract and subsample the undiluted gas sample from the canister into three $12 \mathrm{~mL}$ glass vials (Labco Exetainer, Labco Ltd., Lampeter, Ceredigion, SA48 7HH, UK). Gas samples were analysed using an automated gas analyser equipped with a Gilson Sample Changer (Gilson, Inc., Middleton, WI 53562-0027, USA) modified at NIWA to analyse pressurised air samples in Labco Exetainers, and a GC equipped with a flame-ionisation detector and an electron-capture detector (Hewlett Packard Model 6890, Palo Alto, CA, USA). Separation of $\mathrm{CH}_{4}$ and $\mathrm{SF}_{6}$ was attained using two parallel configured Alltech Porapak-Q 80-100 mesh columns $(3.6 \mathrm{~m} \times 3$ mm stainless steel; Grace Davison Discovery Sciences, Deerfield, IL, USA). The flameionisation detector operated at $250^{\circ} \mathrm{C}$ and the electron-capture detector at $400^{\circ} \mathrm{C}$ using ultrahigh purity nitrogen gas and argon as majority gas with $10 \% \mathrm{CH}_{4}$ added as carrier gasses (30 $\mathrm{mL} / \mathrm{min}$ flow), respectively. Sample loops were flushed away from the flame-ionisation detector so the $\mathrm{CH}_{4}$ in the electron-capture detector carrier gas was not carried through to the 
flame-ionisation detector. A suite of three standards of $\mathrm{SF}_{6}$ and $\mathrm{CH}_{4}$ mixtures from NIWA were associated with the analyses of each batch. Methane production $(\mathrm{g} / \mathrm{d})$ was calculated using equation 2 from the study of Williams et al. (2011).

\subsubsection{Rumen fermentation}

Six rumen-cannulated cows were used in the rumen fermentation study during each 20d sampling period. Indwelling TruTrack pH Data Loggers (Model pH-HR mark 4, Intech Instruments Ltd., Riccarton, Christchurch 8011, NZ), attached to the rumen cannula, were used to log diurnal $\mathrm{pH}$ patterns over a $72 \mathrm{~h}$ period (10 min frequency). Buffer solutions of $\mathrm{pH}$ 4 and 9 were used to calibrate the loggers and buffer solution of $\mathrm{pH} 7$ was used as conformant. Logger drift was tested by placing the calibrated loggers in distilled water for 18 $\mathrm{h}$ where $\mathrm{pH}$ was monitored with a calibrated handheld $\mathrm{pH}$ logger $(\mathrm{pH} 340 \mathrm{i} \mathrm{pH}$ meter/data logger attached with a Sentix 41 pH electrode; WTW, 82362 Weilheim, Germany). A manual vacuum pump was used to collect ruminal fluid $(100 \mathrm{~mL})$ at $8 \mathrm{~h}$ intervals $(0600,1400$ and $2200 \mathrm{~h}$ ) from the ventral sac of each cow. Ruminal pH was immediately measured after sampling with the handheld $\mathrm{pH}$ logger (spot sample $\mathrm{pH}$ ), and successively filtered through cheesecloth (four layers), subsampled in airtight containers and frozen for subsequent $\mathrm{NH}_{3}-\mathrm{N}$ (Broderick and Kang, 1980) and VFA (Filípek and Dvořák, 2009) analysis. The nylon bag procedure of Cruywagen (2006) was used to determine the in sacco DM disappearances of the grazed pasture after 6,18 and $30 \mathrm{~h}$ incubation periods.

\section{$2.5 \quad$ Feed sampling and analysis}

Representative concentrate and pasture samples (one pasture sample consisted of six pooled pasture samples cut approximately $3 \mathrm{~cm}$ above ground level from the successive grazing-strip) were collected weekly, dried at $55^{\circ} \mathrm{C}$ for $72 \mathrm{~h}$ (initial DM), ground to pass through a $1 \mathrm{~mm}$ sieve (SMC hammer mill), and analysed for DM, ash and CP (nitrogen content determined using a LECO TrumacTM N Determinator, LECO Corporation, Saint 
Joseph, MI, USA) according to procedures of AOAC (2000; methods 934.01, 942.05, and 968.06, respectively). Samples were also analysed for NDF content, as described before, gross energy (GE; MC-1000 modular calorimeter, operator's manual), mineral composition (AgriLASA, 1998; method 6.1.1), and in vitro organic matter digestibility (OMD) according to (Tilley and Terry, 1963) using rumen fluid from a rumen-cannulated SA Mutton Merino ram fed good-quality lucern hay. Metabolisable energy (ME) was calculated using the equations of MAFF (1984): $\mathrm{ME}_{\text {concentrate }}=0.84(\mathrm{GE} \times \mathrm{OMD})$, and $\mathrm{ME}_{\text {pasture }}=0.81(\mathrm{GE} \times$ OMD).

\subsection{Statistical analysis}

Milk yield (including FCM and ECM), milk composition, bodyweight change and body condition parameters (18 blocks) over the course of the study and for the duration of the DMI and $\mathrm{CH}_{4}$ measurement period along with DMI and $\mathrm{CH}_{4}$ emissions parameters (10 blocks) were analysed as a randomised complete block design with ANOVA to test for differences between treatment effects. The residuals were acceptably normal with homogeneous treatment variances, except for SCC which were log (base 10) transformed. Covariate analysis was not significant, with pre-experimental milk yield, DIM and parity as covariates; hence, excluded from the statistical analysis.

For the rumen fermentation study (ruminal $\mathrm{pH}$ parameters, fermentation end-products and in sacco DM disappearances) a replicated $3 \times 3$ Latin square design was implemented to test for differences between treatment effects. Time spent below ruminal $\mathrm{pH}$ of 6.6, 6.4, 6.2, 6.0, and 5.8 was Poisson distributed and thus analysed with generalised linear model analysis to test for differences between treatment effects.

Treatment means were compared using Tukey’s least significant difference test at the 5\% level of significance (Snedecor and Cochran, 1980). Data were analysed using the statistical program GenStat (Payne et al., 2014). 
Daily $\mathrm{CH}_{4}$ emissions of individual cows were averaged to yield a single daily value for each cow representative of the entire sampling period. The modified Z-score was used to identify outlying $\mathrm{CH}_{4}$ data. Data associated with 'modified Z-scores' of $>3.5$ (absolute value) were labelled as outliers (Berndt et al., 2014). A 71\% successful collection rate was achieved from the 217 gas samples collected. The remainder was lost due to blockages in the capillary flow restrictor and broken sampling lines during the 24-h collection periods.

\section{Results}

\subsection{Feed composition and pasture measurements}

The chemical composition of the dairy concentrate and pasture offered averaged across the 7-wk study period are presented in Table 1. Cows were offered a daily herbage allowance of $12.2 \mathrm{~kg}$ of DM/cow per day, $3 \mathrm{~cm}$ above ground level, and the average pasture yield was $1.9 \mathrm{t}$ of $\mathrm{DM} / \mathrm{ha}$ (Table 2). The target post-grazing pasture height was $5.5 \mathrm{~cm}$, but the mean measured post-grazing height was $5.85 \mathrm{~cm}$. According to the rising plate meter measurements, cows consumed approximately $73 \%$ of the offered daily herbage allowance.

\subsection{Milk yield, milk composition and cow condition}

Milk yield, FCM and ECM increased linearly $(\mathrm{P}<0.001)$ with increasing level of dairy concentrate (Table 3). Milk composition was unaffected by treatment, except for MUN that decreased linearly $(\mathrm{P}<0.001)$ stepwise with increasing concentrate level, milk protein that increased linearly $(\mathrm{P}=0.027)$, and $\mathrm{SCC}$ that decreased linearly $(\mathrm{P}=0.021)$ with concentrate supplementation. Despite this, milk fat yield, protein yield, and lactose yield increased linearly $(\mathrm{P}<0.001)$ with increasing level of dairy concentrate due to the observed increase in milk yield. Milk fat yield was higher $(\mathrm{P}<0.001)$ for cows receiving concentrate, irrespective of concentrate feeding level, compared with cows on the pasture-only diet. Change in BCS increased linearly $(\mathrm{P}=0.020)$ with increasing concentrate level. 
Table 1. Chemical composition (mean \pm SD) of the concentrate and of the pasture offered averaged across the 7-wk study period

\begin{tabular}{|c|c|c|}
\hline Parameter & $\begin{array}{c}\text { Concentrate } \\
(\mathrm{n}=7)\end{array}$ & $\begin{array}{c}\text { Pasture }^{3} \\
(\mathrm{n}=5)\end{array}$ \\
\hline Initial $\mathrm{DM}^{1}(\%)$ & $89.9 \pm 2.99$ & $13.1 \pm 11.8$ \\
\hline \multicolumn{3}{|l|}{ DM composition ( $\mathrm{g} / \mathrm{kg}$ of DM or as stated) } \\
\hline Crude protein & $132 \pm 2.2$ & $195 \pm 21.9$ \\
\hline Neutral detergent fibre & $92.8 \pm 1.89$ & $493 \pm 24.7$ \\
\hline Ash & $65 \pm 0.8$ & $110 \pm 5.9$ \\
\hline Organic matter digestibility & $933 \pm 30.3$ & $867 \pm 40.0$ \\
\hline Gross energy (MJ/kg of DM) & $17.3 \pm 0.05$ & $17.8 \pm 0.28$ \\
\hline Metabolisable energy $(\mathrm{MJ} / \mathrm{kg} \text { of DM) })^{2}$ & $13.6 \pm 0.47$ & $12.5 \pm 0.61$ \\
\hline $\mathrm{Ca}$ & $12.2 \pm 0.40$ & $4.90 \pm 0.190$ \\
\hline $\mathrm{P}$ & $4.98 \pm 0.093$ & $4.71 \pm 0.309$ \\
\hline $\mathrm{Mg}$ & $3.91 \pm 0.066$ & $3.22 \pm 0.169$ \\
\hline $\mathrm{K}$ & $9.52 \pm 0.199$ & $25.8 \pm 3.89$ \\
\hline $\mathrm{Na}$ & $2.59 \pm 0.077$ & $18.6 \pm 4.41$ \\
\hline $\mathrm{Mn}(\mathrm{mg} / \mathrm{kg}$ of DM) & $93.8 \pm 6.08$ & $53.9 \pm 12.55$ \\
\hline $\mathrm{Cu}(\mathrm{mg} / \mathrm{kg}$ of $\mathrm{DM})$ & $32.5 \pm 4.02$ & $8.84 \pm 1.439$ \\
\hline $\mathrm{Fe}(\mathrm{mg} / \mathrm{kg}$ of $\mathrm{DM})$ & $197 \pm 8.8$ & $155 \pm 27.9$ \\
\hline $\mathrm{Zn}(\mathrm{mg} / \mathrm{kg}$ of $\mathrm{DM})$ & $166 \pm 10.9$ & $49.6 \pm 3.99$ \\
\hline
\end{tabular}

${ }^{1}$ DM-dry matter.

${ }^{2}$ Calculated according to MAFF (1984).

${ }^{3}$ Pasture - perennial ryegrass (Lolium perenne) dominant. 
Table 2. Pre- and post-grazing measurements of the experimental ryegrass pasture averaged (mean \pm SD) across the 7-wk study period

\begin{tabular}{lc}
\hline Parameter & $\begin{array}{c}7 \text {-wk study } \\
(\mathrm{n}=65)\end{array}$ \\
\hline Pasture height $(\mathrm{cm})$ & $11.5 \pm 1.52$ \\
$\quad$ Pre-grazing & $5.85 \pm 0.61$ \\
$\quad$ Post-grazing & \\
Pasture yield $\left(\mathrm{kg}\right.$ of DM/ha) ${ }^{1}$ & $1865 \pm 364$ \\
$\quad$ Pre-grazing & $504 \pm 147$ \\
Post-grazing & $12.2 \pm 1.67$ \\
Daily herbage allowance $(\mathrm{kg}$ of DM/d) & $66.8 \pm 9.33$ \\
Daily grazed area $\left(\mathrm{m}^{2} / \mathrm{cow}\right)$ & $8.90 \pm 1.24$ \\
Pasture removed $(\mathrm{kg}$ of DM/d) & \\
\hline
\end{tabular}

${ }^{1}$ Estimated $5 \mathrm{~cm}$ aboveground level using a rising plate meter; Pasture yield $(\mathrm{kg}$ of DM/ha $)=(120 \times$ rising plate meter height reading) -898 . 
Table 3. The effect of concentrate feeding level on milk production and cow condition of early lactation Jersey cows grazing perennial ryegrass pasture in spring during the 7-wk study

\begin{tabular}{|c|c|c|c|c|c|c|}
\hline \multirow[t]{3}{*}{ Number of cows } & 18 & 18 & 18 & \multirow{3}{*}{$\mathrm{SEM}^{4}$} & \multirow{2}{*}{\multicolumn{2}{|c|}{ P-value }} \\
\hline & \multicolumn{3}{|c|}{ Concentrate level (kg/d as fed) } & & & \\
\hline & 0 & 4 & 8 & & Contrast & Linear \\
\hline Milk yield (kg/d) & $12.6^{\mathrm{c}}$ & $17.1^{\mathrm{b}}$ & $19.1^{\mathrm{a}}$ & 0.42 & $<0.001$ & $<0.001$ \\
\hline FCM yield (kg/d) & $14.0^{\mathrm{c}}$ & $19.0^{\mathrm{b}}$ & $20.7^{\mathrm{a}}$ & 0.46 & $<0.001$ & $<0.001$ \\
\hline ECM yield (kg/d) & $13.8^{\mathrm{c}}$ & $19.0^{\mathrm{b}}$ & $20.8^{\mathrm{a}}$ & 0.47 & $<0.001$ & $<0.001$ \\
\hline Milk fat $(\mathrm{g} / \mathrm{kg})$ & 47.5 & 47.7 & 45.8 & 0.78 & 0.18 & 0.13 \\
\hline Milk protein $(\mathrm{g} / \mathrm{kg})$ & 35.2 & 36.3 & 36.4 & 0.37 & 0.047 & 0.027 \\
\hline Milk lactose (g/kg) & 46.3 & 46.7 & 46.5 & 0.23 & 0.46 & 0.43 \\
\hline $\operatorname{Milk~solids}^{2}(\mathrm{~g} / \mathrm{kg})$ & 129 & 131 & 129 & 1.0 & 0.28 & 0.91 \\
\hline MUN (mg/dL) & $13.6^{\mathrm{a}}$ & $11.6^{\mathrm{b}}$ & $9.21^{\mathrm{c}}$ & 0.283 & $<0.001$ & $<0.001$ \\
\hline $\log _{10} \mathrm{SCC}$ & 2.23 & 2.22 & 1.94 & 0.084 & 0.031 & 0.021 \\
\hline Milk fat yield (kg/d) & $0.60^{\mathrm{b}}$ & $0.81^{\mathrm{a}}$ & $0.87^{\mathrm{a}}$ & 0.021 & $<0.001$ & $<0.001$ \\
\hline Milk protein yield (kg/d) & $0.44^{\mathrm{c}}$ & $0.62^{\mathrm{b}}$ & $0.69^{\mathrm{a}}$ & 0.015 & $<0.001$ & $<0.001$ \\
\hline Milk lactose yield (kg/d) & $0.58^{c}$ & $0.80^{\mathrm{b}}$ & $0.89^{\mathrm{a}}$ & 0.022 & $<0.001$ & $<0.001$ \\
\hline Body weight change (kg) & -1.28 & +4.44 & +6.44 & 2.900 & 0.16 & 0.17 \\
\hline Body condition score change ${ }^{3}$ & +0.03 & +0.10 & +0.17 & 0.040 & 0.065 & 0.020 \\
\hline
\end{tabular}

a,b,c Means in the same row with different superscripts differ $(\mathrm{P}<0.05)$.

${ }^{1}$ FCM-4\% fat corrected milk (calculated); ECM-energy corrected milk (calculated); MUN-milk urea nitrogen; SCC-somatic cell count.

${ }^{2}$ Milk solids $=$ milk fat + milk protein + milk lactose .

${ }^{3}$ Scale 1 to 5 .

${ }^{4}$ SEM-standard error of mean. 
Table 4. The effect of concentrate feeding level on dry matter intake, methane emissions and milk production of early lactation Jersey cows grazing perennial ryegrass pasture in spring during the methane measurement period

\begin{tabular}{|c|c|c|c|c|c|c|}
\hline \multirow{3}{*}{$\begin{array}{l}\text { Number of cows } \\
\text { Parameter }^{1}\end{array}$} & 10 & 10 & 10 & \multirow{3}{*}{$\mathrm{SEM}^{2}$} & \multirow{2}{*}{\multicolumn{2}{|c|}{ P-value }} \\
\hline & \multicolumn{3}{|c|}{ Concentrate level (kg/d as fed) } & & & \\
\hline & 0 & 4 & 8 & & Contrast & Linear \\
\hline Faecal output (kg of DM/d) & 2.21 & 2.47 & 2.42 & 0.14 & 0.40 & 0.31 \\
\hline \multicolumn{7}{|l|}{ Intake } \\
\hline Pasture DMI $(\mathrm{kg} / \mathrm{d})$ & 13.4 & 12.8 & 10.8 & 0.81 & 0.082 & 0.034 \\
\hline Total DMI (kg/d) & $13.4^{\mathrm{b}}$ & $16.4^{\mathrm{a}}$ & $18.0^{\mathrm{a}}$ & 0.81 & 0.003 & $<0.001$ \\
\hline $\mathrm{BW}(\mathrm{kg})$ & 414 & 402 & 395 & 11.7 & 0.52 & 0.27 \\
\hline NDF intake as $\%$ of BW & 1.63 & 1.66 & 1.53 & 0.113 & 0.67 & 0.54 \\
\hline DMI as $\%$ of BW & $3.30^{\mathrm{b}}$ & $4.11^{\mathrm{ab}}$ & $4.57^{\mathrm{a}}$ & 0.236 & 0.004 & 0.001 \\
\hline GEI $(\mathrm{MJ} / \mathrm{d})$ & $239^{\mathrm{b}}$ & $290^{\mathrm{ab}}$ & $316^{\mathrm{a}}$ & 14.5 & 0.005 & 0.001 \\
\hline MEI (MJ/d) & $168^{\mathrm{b}}$ & $209^{\mathrm{a}}$ & $233^{\mathrm{a}}$ & 10.2 & $<0.001$ & $<0.001$ \\
\hline $\mathrm{CP}$ intake $(\mathrm{kg} / \mathrm{d})$ & 2.62 & 2.97 & 3.05 & 0.16 & 0.15 & 0.068 \\
\hline \multicolumn{7}{|l|}{$\mathrm{CH}_{4}$ emissions } \\
\hline $\mathrm{CH}_{4}$ production $(\mathrm{g} / \mathrm{d})$ & 258 & 321 & 302 & 20.0 & 0.107 & 0.15 \\
\hline $\mathrm{CH}_{4} / \mathrm{DMI}(\mathrm{g} / \mathrm{kg})$ & 20.6 & 19.6 & 16.9 & 1.86 & 0.37 & 0.18 \\
\hline $\mathrm{CH}_{4} /$ milk yield $(\mathrm{g} / \mathrm{kg})$ & 20.4 & 19.8 & 15.9 & 1.36 & 0.063 & 0.031 \\
\hline $\mathrm{CH}_{4} / \mathrm{ECM}(\mathrm{g} / \mathrm{kg})$ & 17.9 & 17.4 & 14.6 & 1.28 & 0.18 & 0.088 \\
\hline $\mathrm{CH}_{4} / \mathrm{FCM}(\mathrm{g} / \mathrm{kg})$ & 17.7 & 17.3 & 14.9 & 1.30 & 0.30 & 0.16 \\
\hline $\mathrm{CH}_{4}$ energy $(\mathrm{MJ} / \mathrm{d})$ & 14.3 & 17.7 & 16.7 & 1.10 & 0.107 & 0.15 \\
\hline $\mathrm{Ym}(\%)$ & 6.38 & 6.12 & 5.30 & 0.580 & 0.41 & 0.20 \\
\hline Milk yield (kg/d) & $12.9^{c}$ & $16.7^{b}$ & $19.2^{\mathrm{a}}$ & 0.40 & $<0.001$ & $<0.001$ \\
\hline $\mathrm{FCM}(\mathrm{kg} / \mathrm{d})$ & $14.8^{b}$ & $19.0^{\mathrm{a}}$ & $20.3^{\mathrm{a}}$ & 0.44 & $<0.001$ & $<0.001$ \\
\hline $\mathrm{ECM}(\mathrm{kg} / \mathrm{d})$ & $14.6^{\mathrm{c}}$ & $18.9^{\mathrm{b}}$ & $20.7^{\mathrm{a}}$ & 0.45 & $<0.001$ & $<0.001$ \\
\hline Milk fat (g/kg) & $50.0^{\mathrm{a}}$ & $49.4^{\mathrm{a}}$ & $44.2^{\mathrm{b}}$ & 1.34 & 0.013 & 0.007 \\
\hline Milk protein $(\mathrm{g} / \mathrm{kg})$ & 35.8 & 36.5 & 36.8 & 0.49 & 0.30 & 0.14 \\
\hline Milk lactose (g/kg) & $46.2^{b}$ & $46.6^{\mathrm{b}}$ & $48.1^{\mathrm{a}}$ & 0.39 & 0.008 & 0.003 \\
\hline
\end{tabular}

a,b,c Means in the same row with different superscripts differ $(\mathrm{P}<0.05)$.

${ }^{1}$ DMI-dry matter intake; BW-body weight; NDF-neutral detergent fibre; GEI-gross energy intake; MEI-metabolisable energy intake; $\mathrm{CP}$-crude protein; $\mathrm{CH}_{4}$-methane; $\mathrm{FCM}-4 \%$ fat corrected milk (calculated); ECM-energy corrected milk (calculated); $\mathrm{Ym}-\mathrm{CH}_{4}$ energy per GEI.

${ }^{2}$ SEM-standard error of mean. 


\subsection{Dry matter intake and enteric methane emissions}

Faecal output was unaffected $(\mathrm{P}>0.05)$ by treatment, whereas pasture DMI decreased linearly $(\mathrm{P}=0.034)$ and total DMI increased linearly $(\mathrm{P}=<0.001)$ with increasing concentrate feeding level (Table 4). Total DMI was the highest for both the 4 and $8 \mathrm{~kg}$ groups while being the lowest $(\mathrm{P}=0.003)$ for the $0 \mathrm{~kg}$ group. Furthermore, total DMI per kg bodyweight, GE intake and ME intake increased linearly $(\mathrm{P}<0.05)$ with increasing concentrate feeding level. Cows fed the $8 \mathrm{~kg}$ concentrate level had a higher $(\mathrm{P}=0.004)$ total DMI per $\mathrm{kg}$ bodyweight and a higher $(\mathrm{P}=0.005) \mathrm{GE}$ intake compared with those fed the $0 \mathrm{~kg}$ level, but similar $(\mathrm{P}>0.05)$ to those fed the $4 \mathrm{~kg}$ level. Furthermore, cows fed the 4 and $8 \mathrm{~kg}$ concentrate level had similar $(\mathrm{P}>0.05)$ ME intakes, but higher $(\mathrm{P}<0.001)$ than those on the pasture-only diet. In contrast, NDF intake per kg bodyweight was not affected $(\mathrm{P}>0.05)$ by treatment. Individual $\mathrm{CP}$ intake tended to increase linearly $(\mathrm{P}=0.068)$ with increasing concentrate feeding level. Methane production $(\mathrm{g} / \mathrm{d})$ and $\mathrm{CH}_{4}$ energy $(\mathrm{MJ} / \mathrm{d})$ tended to increase $(\mathrm{P}=0.107)$ with concentrate supplementation. It was also observed that $\mathrm{CH}_{4}$ intensity, in the form of $\mathrm{g} / \mathrm{kg}$ of milk yield decreased linearly $(\mathrm{P}=0.031)$ and tended to decrease $(\mathrm{P}=0.088)$ in the form of $\mathrm{g} / \mathrm{kg}$ of ECM with increasing concentrate feeding level. Methane yield $(\mathrm{g} / \mathrm{d})$ and $\mathrm{CH}_{4}$ intensity in the form of $\mathrm{g} / \mathrm{kg}$ of $\mathrm{FCM}$, were unaffected $(\mathrm{P}>0.05)$ by concentrate supplementation.

The effect of concentrate level on milk production and milk composition recorded during the $\mathrm{CH}_{4}$ measurement period are presented in Table 4. Milk yield, FCM and ECM obtained during the $\mathrm{CH}_{4}$ measurement period reflected the same trend as that of the 7-wk study period (Table 3), by increasing linearly $(\mathrm{P}<0.001)$ with increasing concentrate level. The treatment effect on FCM observed during the $\mathrm{CH}_{4}$ measurement period did not increase stepwise with increasing concentrate level, as in the case of the 7-wk study period, but exhibited only an increase $(\mathrm{P}<0.001)$ for cows receiving concentrate, irrespective of 
concentrate level. Furthermore, milk protein content did not differ, whereas milk fat content decreased linearly $(\mathrm{P}=0.007)$ while milk lactose content increased linearly $(\mathrm{P}=0.003)$ with increasing concentrate feeding level, which was not the case during the 7-wk study period (Table 3). Milk fat content was higher $(\mathrm{P}=0.013)$ for cows on both the 0 and $4 \mathrm{~kg}$ than those on the $8 \mathrm{~kg}$ concentrate level. Cows in the $8 \mathrm{~kg}$ group had a higher $(\mathrm{P}=0.008)$ milk lactose content compared to the other treatment groups.

\subsection{Rumen fermentation}

The effect of concentrate feeding level on diurnal ruminal $\mathrm{pH}$, as recorded by the indwelling $\mathrm{pH}$ logging system, is depicted in Fig. 1. It was noticeable that ruminal $\mathrm{pH}$ of cows fed the $8 \mathrm{~kg}$ concentrate level decreased $(\mathrm{P}<0.05) 1 \mathrm{~h}$ after receiving the morning concentrate and remained lower $(\mathrm{P}<0.05)$ than the other groups for approximately $2.5 \mathrm{~h}$ before recovering. Subsequently, $1 \mathrm{~h}$ after cows received the afternoon concentrate, ruminal $\mathrm{pH}$ of the 4 and $8 \mathrm{~kg}$ group decreased $(\mathrm{P}<0.05)$ and remained lower than the $0 \mathrm{~kg}$ group for $30 \mathrm{~min}$, where after the $\mathrm{pH}$ of the $8 \mathrm{~kg}$ group decreased even lower $(\mathrm{P}<0.05)$ than that of the 4 $\mathrm{kg}$ group. This continued for $1 \mathrm{~h}$ before the $\mathrm{pH}$ of the $4 \mathrm{~kg}$ group recovered $(\mathrm{P}>0.05)$ to that of the $0 \mathrm{~kg}$ group while the $\mathrm{pH}$ of the $8 \mathrm{~kg}$ group remained the lowest $(\mathrm{P}<0.05)$ for an additional hour. During the course of the evening and early morning cows on the $4 \mathrm{~kg}$ and 8 $\mathrm{kg}$ concentrate level showed intermittent decreases $(\mathrm{P}<0.05)$ in $\mathrm{pH}$ compared with the $0 \mathrm{~kg}$ group. Mean diurnal ruminal $\mathrm{pH}$ (averaged over $72 \mathrm{~h}$ ) tended to decrease linearly $(\mathrm{P}=0.082)$ with increasing concentrate feeding level (Table 5). Furthermore, a linear increasing trend $(\mathrm{P}=0.079)$ was evident in time spent below ruminal $\mathrm{pH}$ of 6.2 as concentrate feeding level increased. Ruminal $\mathrm{NH}_{3}-\mathrm{N}$ concentration increased linearly $(\mathrm{P}=0.007)$ with increasing concentrate feeding level, with cows fed concentrate, irrespective of feeding level, having a greater $(\mathrm{P}=0.002)$ ruminal $\mathrm{NH}_{3}-\mathrm{N}$ concentration than cows on the pasture-only diet. Total VFA concentration was unaffected by treatment, however isobutyric acid tended to increase 
$(\mathrm{P}=0.089)$ with increasing concentrate feeding level. Pasture in sacco DM disappearance, after 6, 18 and $30 \mathrm{~h}$ incubation, decreased linearly $(\mathrm{P}<0.05)$ with increasing concentrate feeding level. The pasture-only group had a higher $(\mathrm{P}=0.006)$ in sacco $\mathrm{DM}$ disappearance than the $4 \mathrm{~kg}$ and $8 \mathrm{~kg}$ group after $18 \mathrm{~h}$ incubation, but only higher $(\mathrm{P}<0.05)$ than the $8 \mathrm{~kg}$ group after $6 \mathrm{~h}$ and $30 \mathrm{~h}$ incubation.

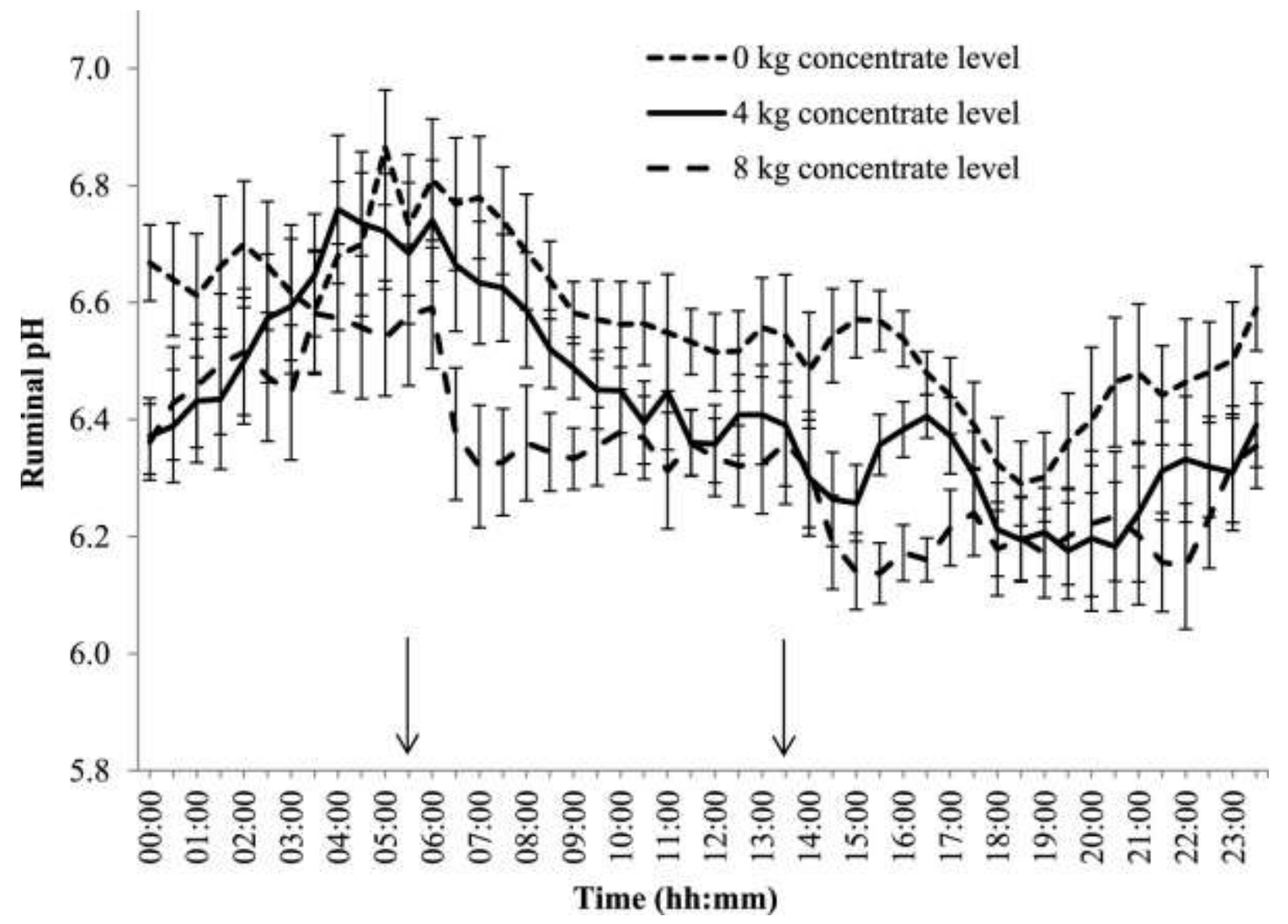

Fig. 1. The effect of concentrate supplementation level (as fed) on diurnal ruminal pH of early lactation Jersey cows grazing perennial ryegrass pasture during spring $(n=6)$. Error bars indicate SEM and arrows indicated when concentrate was fed. 
Table 5. The effect of concentrate supplementation level on ruminal $\mathrm{pH}$, volatile fatty acid profile, $\mathrm{NH}_{3}-\mathrm{N}$ concentration, and dry matter disappearance of early lactation Jersey cows grazing perennial ryegrass pasture in spring (mean of the rumen measurement periods)

\begin{tabular}{|c|c|c|c|c|c|c|}
\hline \multirow{3}{*}{$\begin{array}{l}\text { Number of cows } \\
\text { Parameter }^{1}\end{array}$} & 6 & 6 & 6 & \multirow{3}{*}{$\mathrm{SEM}^{2}$} & \multirow{2}{*}{\multicolumn{2}{|c|}{ P-value }} \\
\hline & \multicolumn{3}{|c|}{ Concentrate level (kg/d as fed) } & & & \\
\hline & 0 & 4 & 8 & & Contrast & Linear \\
\hline Diurnal pH (over 72 h) & 6.57 & 6.39 & 6.33 & 0.075 & 0.17 & 0.082 \\
\hline Spot sample pH & 6.22 & 6.13 & 6.09 & 0.046 & 0.23 & 0.11 \\
\hline \multicolumn{7}{|l|}{ Time below (h) } \\
\hline pH 5.8 & 0.00 & 0.57 & 0.08 & 0.213 & 0.22 & 0.79 \\
\hline pH 6.0 & 0.42 & 2.50 & 2.58 & 1.010 & 0.31 & 0.19 \\
\hline $\mathrm{pH} 6.2$ & 3.20 & 6.80 & 9.20 & 1.950 & 0.18 & 0.079 \\
\hline pH 6.4 & 8.90 & 11.2 & 13.4 & 2.350 & 0.46 & 0.23 \\
\hline pH 6.6 & 14.3 & 15.5 & 20.4 & 3.13 & 0.41 & 0.23 \\
\hline $\mathrm{NH}_{3}-\mathrm{N}(\mathrm{mg} / \mathrm{dL})$ & $6.35^{\mathrm{b}}$ & $13.0^{\mathrm{a}}$ & $10.4^{\mathrm{a}}$ & 0.713 & 0.002 & 0.007 \\
\hline Total VFA (mM/L) & 91.8 & 91.5 & 91.7 & 4.68 & 0.99 & 1.00 \\
\hline Acetic $(\mathrm{m} M \%)$ & 65.3 & 65.6 & 65.1 & 0.68 & 0.88 & 0.87 \\
\hline Propionic (mM \%) & 18.1 & 18.2 & 18.6 & 0.53 & 0.80 & 0.54 \\
\hline Acetic to Propionic ratio & 3.62 & 3.63 & 3.52 & 0.133 & 0.80 & 0.59 \\
\hline Butyric (mM \%) & 13.5 & 13.1 & 13.0 & 0.28 & 0.48 & 0.26 \\
\hline Isobutyric (mM\%) & 0.90 & 0.86 & 0.97 & 0.027 & 0.089 & 0.12 \\
\hline Valeric $(\mathrm{m} M \%)$ & 1.07 & 1.05 & 1.07 & 0.031 & 0.92 & 1.00 \\
\hline Isovaleric ( $\mathrm{m} M \%)$ & 1.03 & 0.99 & 1.08 & 0.063 & 0.66 & 0.61 \\
\hline Caproic (mM\%) & 0.22 & 0.25 & 0.27 & 0.019 & 0.29 & 0.14 \\
\hline \multicolumn{7}{|c|}{ DM disappearance (coefficient) } \\
\hline $6 \mathrm{~h}$ & $0.41^{\mathrm{a}}$ & $0.38^{\mathrm{ab}}$ & $0.36^{\mathrm{b}}$ & 0.011 & 0.038 & 0.014 \\
\hline $18 \mathrm{~h}$ & $0.67^{\mathrm{a}}$ & $0.64^{\mathrm{b}}$ & $0.62^{\mathrm{b}}$ & 0.012 & 0.006 & $<0.001$ \\
\hline $30 \mathrm{~h}$ & $0.85^{\mathrm{a}}$ & $0.83^{\mathrm{ab}}$ & $0.80^{\mathrm{b}}$ & 0.010 & 0.022 & 0.008 \\
\hline
\end{tabular}

a,b,c Means in the same row with different superscripts differ $(\mathrm{P}<0.05)$.

${ }^{1} \mathrm{NH}_{3}-\mathrm{N}$-ammonia nitrogen; VFA-volatile fatty acid; DM-dry matter.

${ }^{2}$ SEM-standard error of mean. 


\section{Discussion}

This study aimed to compare early lactation dairy cows grazing perennial ryegrass pasture during spring on the basis of DMI, milk production, rumen fermentation and $\mathrm{CH}_{4}$ emissions; one group received zero concentrate, the second group received $4 \mathrm{~kg}$ (as fed) of concentrate, whereas the third group received $8 \mathrm{~kg}$ (as fed) of concentrate.

Pasture grazed in this study was comparable, in terms of botanical composition and quality, to that of pasture, one year after perennial ryegrass establishment, as reported by van der Colf et al. (2015), and also closely resembled the pasture quality of previous grazing studies that evaluated the effect of concentrate level on $\mathrm{CH}_{4}$ emissions (Jiao et al., 2014; Muñoz et al., 2015). In addition, the quality of this pasture was of excellent standard (OMD>81\%) which could result in a higher pasture DMI when compared with pasture having a lower OMD (Peyraud and Delagarde, 2013). The pre-grazing pasture yield or pasture mass in the current study (1865 $\mathrm{kg}$ of DM/ha) is within the range of previous grazing studies (1000 to $3800 \mathrm{~kg}$ of DM/ha) as summarised in a meta-analysis evaluating the effect of pre-grazing pasture mass on several different dairy cow production parameters (Pérez-Prieto and Delagarde, 2012). Pasture DMI (kg/cow per day) as determined with the rising plate meter was $28 \%$ (8.9vs. 12.3) lower than the pasture DMI averaged across the treatments as determined with $\mathrm{TiO}_{2}$ and $\mathrm{iNDF}$. This discrepancy shows that pasture DMI estimated by both the $\mathrm{TiO}_{2} / \mathrm{NDF}$ method and by the rising plate meter method should be interpreted with caution. Furthermore, we observed that pasture DMI decreased linearly with increasing concentrate level, indicating that a certain degree of pasture substitution was evident. Substitution rate is influenced by several pasture, animal and supplement factors, with pasture yield, daily herbage allowance and pasture quality (OMD) being identified as the most important pasture-related-factors (Bargo et al., 2003). In the current study the substitution rate ( $\mathrm{kg}$ of pasture $\mathrm{DMI} / \mathrm{kg}$ of concentrate $\mathrm{DMI})$, calculated relative to the pasture-only 
treatment, was 0.15 and 0.33 for the $4 \mathrm{~kg}$ and $8 \mathrm{~kg}$ concentrate group, respectively, and were in agreement with previous grazing studies as reported by Bargo et al. (2003). Additionally, substitution rate is negatively correlated to milk response (Stockdale, 2000), as was seen here where the milk response ( $\mathrm{kg}$ of milk/kg of concentrate) decreased as the concentrate level and substitution rate increased during the $\mathrm{CH}_{4}$ measurement period; 1.06 and 0.88 increasing from the 0 to $4 \mathrm{~kg}$ and 0 to $8 \mathrm{~kg}$ of concentrate level, respectively, while a marginal milk response of 0.70 was attained when comparing the $4 \mathrm{~kg}$ to the $8 \mathrm{~kg}$ concentrate levels.

From a meta-analysis that included 211 concentrate supplementation studies using lactating dairy cows, Huhtanen and Hetta (2012) reported marginal positive responses between concentrate DMI and total DMI, milk yield, ECM yield, and milk protein and milk lactose content, and marginal negative responses between concentrate DMI and forage DMI, and milk fat content. Similar responses were observed in our study during the $\mathrm{CH}_{4}$ measurement period, except for milk protein content that remained unchanged by concentrate feeding level in agreement with previously published grazing studies evaluating the effect of concentrate level on $\mathrm{CH}_{4}$ emissions and milk production responses (Lovett et al., 2005; Muñoz et al., 2015). This response reflects the decreasing marginal CP intake with increasing concentrate feeding level. Furthermore, Roseler et al. (1993) stated that MUN decreases as the diet CP:ME ratio decreases, as was evident in the current study where the diet CP:ME ratio decreased from 1.56 to 1.32 changing from the $0 \mathrm{~kg}$ to the $8 \mathrm{~kg}$ treatment as a result of the observed increase in energy intake as concentrate level increased.

Rumen fermentation parameters such as VFA concentration, $\mathrm{pH}$, disappearance coefficients and $\mathrm{NH}_{3}-\mathrm{N}$ can act, in some instances, as marginal proxies for milk production responses to feed alterations such as concentrate feeding level (Bargo et al., 2003). In the present study concentrate level did not impact biologically significant on the VFA profile and ruminal $\mathrm{pH}$, however $\mathrm{DM}$ disappearance and $\mathrm{NH}_{3}-\mathrm{N}$ concentration were affected by 
concentrate supplementation. The decrease in DM disappearance with increasing concentrate feeding level was also reported by Bargo et al. (2013), however the increase in $\mathrm{NH}_{3}-\mathrm{N}$ concentration with increasing concentrate feeding level is in contrast with the findings of Bargo et al. (2003). In the current study, the increased $\mathrm{NH}_{3}-\mathrm{N}$ concentration is supported by the observed increasing trend in $\mathrm{CP}$ intake towards increasing concentrate feeding level, which could lead to an increase in ruminally degradable CP. Additionally, this indicates that the pasture in the current study should have a lower $\mathrm{CP}$ content or ruminally degradable $\mathrm{CP}$ content than the pasture evaluated in the review study of Bargo et al. (2003). This discrepancy reflects the complexity of the relationship between concentrate level and rumen fermentation patterns on pasture-based systems. Regardless, the recurrent pattern of the diurnal ruminal $\mathrm{pH}$ variation around concentrate feeding time, as observed in the current study, is in agreement with Bargo et al. (2002) who reported that ruminal $\mathrm{pH}$ is the highest pre-concentrate feeding and lowest post-concentrate feeding.

Feeding high levels of concentrates has been identified as an effective enteric $\mathrm{CH}_{4}$ mitigation strategy for cattle (Hristov et al., 2013; Knapp et al., 2014), albeit there are limited studies that have evaluated the effect of concentrate feeding level on enteric $\mathrm{CH}_{4}$ emissions from grazing dairy cows. Lovett et al. (2005) reported an increase in $\mathrm{CH}_{4}$ emissions (346 vs. $399 \mathrm{~g} / \mathrm{d}$ ) and a tendency for decreased $\mathrm{CH}_{4}$ emissions per kilogram fat corrected milk (FCM; 21.0 vs. $17.7 \mathrm{~g} / \mathrm{kg}$ ), while Jiao et al. (2014) reported a decrease in $\mathrm{CH}_{4}$ emissions per kilogram energy corrected milk (ECM; 14.1 to $11.1 \mathrm{~g} / \mathrm{kg}$ ), per kilogram milk yield (15.4 to $10.8 \mathrm{~g} / \mathrm{kg}$ ), and per kilogram DMI (20.0 to $18.1 \mathrm{~g} / \mathrm{kg}$ ) when the concentrate level increased from 1 to $6 \mathrm{~kg}$ (as fed), and increased in $2 \mathrm{~kg}$ increments from 2 to $8 \mathrm{~kg}$ (as fed), respectively. In another study when concentrate level increased from 1 to $5 \mathrm{~kg}$ (as fed), $\mathrm{CH}_{4}$ emissions (323 vs. $357 \mathrm{~g} / \mathrm{d}$ for period 1, and 349 vs. $390 \mathrm{~g} / \mathrm{d}$ for period 2) increased with increasing concentrate level (Muñoz et al., 2015). This discrepancy in the response of $\mathrm{CH}_{4}$ emissions to 
concentrate feeding level can be attributed to different pasture DMI responses (as affected by several factors including daily herbage allowance and pasture substitution rate), method of estimating DMI and $\mathrm{CH}_{4}$ emissions, and the statistical power of the experimental design.

When comparing our results to these limited grazing studies, we found that the average $\mathrm{CH}_{4}$ emissions in the current study (294 vs. $277 \mathrm{~g} / \mathrm{d}$ ) closely resembles that of Jiao et al. (2014), who also fed a maximum concentrate level of $8 \mathrm{~kg} / \mathrm{d}$, but to Holstein-Friesians, while also reporting no treatment effect on $\mathrm{CH}_{4}$ emissions (g/d). In the latter study, a pasture substitution rate of 0.73 was evident between the two extreme concentrate levels $(2$ and 8 $\mathrm{kg} / \mathrm{d}$ ), compared with 0.50 in the current study. This difference in substitution rate, most probably, led to the observed decrease in pasture DMI in the study of Jiao et al. (2014), whilst not in the current study. Additionally, the pasture-only group in the current study produced similar $\mathrm{CH}_{4}$ emissions to that of the pasture-only group $(258 v s .251 \mathrm{~g} / \mathrm{d} ; 20.6$ vs. $18.1 \mathrm{~g} / \mathrm{kg}$ of DMI; 6.4 vs. $5.7 \% \mathrm{CH}_{4}$ energy per GEI (Ym), respectively) in a study of O'Neill et al. (2011), where the authors compared $\mathrm{CH}_{4}$ emissions from Holstein-Friesian cows on a pasture-only diet (100\% Lolium perenne L.) to cows on a total mixed ration diet. On the contrary, other grazing studies that evaluated the effect of concentrate feeding level on $\mathrm{CH}_{4}$ emissions yielded greater average $\mathrm{CH}_{4}$ emissions (294 vs. 372, and 355; Lovett et al. 2005, and Muñoz et al., 2015, respectively), compared with the current study. This could possibly be attributed to the greater feed intakes observed in those studies. The average $\mathrm{CH}_{4}$ yield $(19.0 \mathrm{~g} / \mathrm{kg}$ of DMI) was similar to average values reported in previous grazing studies, all of which implemented the $\mathrm{SF}_{6}$ technique to measure $\mathrm{CH}_{4}$ emissions: 18.7 (Lovett et al., 2005); 19.2 (O’Neill et al., 2011), 18.8 (Jiao et al., 2014), and 19.2 (Muñoz et al., 2015). Whereas, the average $\mathrm{CH}_{4}$ intensity $(18.7 \mathrm{~g} / \mathrm{kg}$ of milk yield) was greater than that reported by Jiao et al. (2014) and Muñoz et al. (2015), 12.6 and 13.6, respectively, but more closely related to the value of 19.4 as reported by Lovett et al. (2005). This difference can be ascribed to the 
greater milk production of the Holstein-Friesian cows, in the studies of Jiao et al. (2014) and Muñoz et al. (2015), compared with that of Jersey cows (NRC, 2001). Whereas the similarity can be ascribed to the high fibre diet, induced by the fibre-based concentrate and pasture species present in the study of Lovett et al. (2005), that has been reported to reduce milk production (Bargo et al., 2003). The lack of a linear response in $\mathrm{CH}_{4}$ yield and intensity $(\mathrm{g} / \mathrm{kg}$ of ECM) was in agreement with Muñoz et al. (2015). These authors attributed their $\mathrm{CH}_{4}$ intensity results to their milk response of $0.6 \mathrm{~kg}$ of milk/ $\mathrm{kg}$ of concentrate $(1$ and $5 \mathrm{~kg}$ concentrate level), being the threshold for dilution of maintenance requirements over greater milk production units that could be a mechanism for reducing $\mathrm{CH}_{4}$ intensity. Other factors as parity, DIM, breed, and pasture botanical composition and quality should not be ignored while interpreting enteric $\mathrm{CH}_{4}$ emissions from grazing studies as all these factors, and more, can influence enteric $\mathrm{CH}_{4}$ emissions from dairy cows (Muñoz et al., 2015).

When interpreting the VFA and $\mathrm{pH}$ results in relation to the $\mathrm{CH}_{4}$ emission results obtained in this study, the observed similar $\mathrm{CH}_{4}$ emissions between treatments can be explained, in part, by the similar acetic to propionic acid ratio and ruminal $\mathrm{pH}$ that were also observed between treatments. van Kessel and Russell (1994) reported that $\mathrm{pH}$ might be linked to enteric $\mathrm{CH}_{4}$ emissions (a lower ruminal $\mathrm{pH}$ might inhibit $\mathrm{CH}_{4}$ producing microbes), while van Nevel and Demeyer (1996) reported that the acetic to propionic acid ratio in the rumen is also linked to enteric $\mathrm{CH}_{4}$ emissions (propionate production inhibits methanogenesis by reducing the availability of metabolic $\mathrm{H}_{2}$ ). However, the occurrence of a weak, increasing trend in $\mathrm{CH}_{4}$ emissions with concentrate supplementation supports the theory regarding ruminal VFA concentrations and $\mathrm{pH}$ as individual proxies for enteric $\mathrm{CH}_{4}$ emissions as indicated by Negussie et al. (2017). In support of this, Aguerre et al. (2011) concluded that $\mathrm{CH}_{4}$ emissions could not, solely, be predicted from VFA patterns in a study where the effect 
of forage-to-concentrate ratio (47 to $68 \%$ forage) on $\mathrm{CH}_{4}$ emissions of dairy cows was evaluated.

It is well documented that there is a strong linear relationship between DMI and enteric $\mathrm{CH}_{4}$ emissions (Hristov et al., 2013; Knapp et al., 2014; Charmley et al., 2016). However, increasing the OMD or quality of the diet (by feeding grain-based concentrates) may increase the starch:NDF ratio, and because less $\mathrm{CH}_{4}$ is generated per unit of starch digested than NDF (Moe and Tyrrell, 1979), a reduction in $\mathrm{CH}_{4}$ emissions (g/d) and intensity (by increased animal production) is expected. Therefore, the slightly higher OMD of the concentrate fed (93\%) compared with the pasture offered (87\%) was barely sufficient, as supported by the similar NDF intake/body weight between treatments, to increase the diet OMD to a point to maintain daily $\mathrm{CH}_{4}$ emissions, despite the observed increase in DMI with concentrate supplementation. This occurrence was also evident in the grazing study of Jiao et al. (2014) in which the effect of concentrate level $(2,4,6$, and $8 \mathrm{~kg} / \mathrm{d})$ on $\mathrm{CH}_{4}$ emissions was evaluated.

The observed $\mathrm{CH}_{4}$ energy $(\mathrm{MJ} / \mathrm{d})$ in the current study is within the range of 13.6 to 22.1 as reported by Eckard et al. (2010) for lactating dairy cows, and tended to increase when the pasture-only diet was supplemented with concentrate, regardless of the feeding level. This was probably due to the observed increase in GE intake with increasing concentrate feeding level. The average $\mathrm{Ym}(5.9 \%)$ of this study is in agreement with previously reported values of 5.6\% (Jiao et al., 2014) and 6.3\% (Muñoz et al., 2015). Albeit observing no treatment effect on Ym, numerically the values of the current study are similar to that of Tyrrell and Moe (1972), who observed that $\mathrm{Ym}$ was reduced from 6.4 to 5.1\% when the concentrate:forage ratio increased from 0.31 to 0.59 ( 0 to 0.60 in the current study).

Furthermore, high coefficients of variation $(\mathrm{CV})$ in $\mathrm{CH}_{4}$ yield could also affect $\mathrm{CH}_{4}$ emission responses to diet treatment, and could be accounted for by increasing the statistical power of the $\mathrm{SF}_{6}$ experiment by increasing animal numbers per treatment. The between- 
animal $\mathrm{CV}$ for $\mathrm{CH}_{4}$ yield of the few published grazing studies evaluating the effect of concentrate feeding level on $\mathrm{CH}_{4}$ emissions from dairy cows was not published, therefore making comparisons difficult. Nonetheless, Deighton et al. (2014) reported that previously published between-animal CV ranged from 11 to $24.5 \%$, with their own between-animal CV reported as low as $6.5 \%$ when using their modified $\mathrm{SF}_{6}$ technique. However, it should be emphasised that $\mathrm{CH}_{4}$ emissions measured, using the $\mathrm{SF}_{6}$ technique, during the latter studies, was performed on animals in confinement, and not under grazing conditions that is renowned for the challenges associated with measuring $\mathrm{CH}_{4}$ emissions and pasture DMI. Even though the between-cow $\mathrm{CV}$ in $\mathrm{CH}_{4}$ yield in the current grazing study was at a high of $31 \%(21.5 \%$ for $\mathrm{CH}_{4}$ emissions $(\mathrm{g} / \mathrm{d})$, and $16.1 \%$ for total $\left.\mathrm{DMI}\right), \mathrm{CH}_{4}$ emission values are in agreement with literature, but may also explain the observed tendencies and lack of response in $\mathrm{CH}_{4}$ emissions towards an increasing concentrate feeding level, despite the observed increases in milk production and total DMI. In the current study, the implemented strict daily herbage allowance could have caused competitive and aggressive behaviour between cows and some cows may have had variable pasture DMI from day to day. This could be an explanation for the high between-cow $\mathrm{CV}$ in $\mathrm{CH}_{4}$ yield. Therefore, we encourage the use of more than 10 animals to account for high between-animal $\mathrm{CV}$ when conducting $\mathrm{SF}_{6}$ experiments under grazing conditions. Regardless, this study showed that the supplementation of concentrate to a pasture-only diet, increased milk production and total DMI, and linearly decreased $\mathrm{CH}_{4}$ intensity ( $\mathrm{g} / \mathrm{kg}$ of milk yield).

\section{Conclusions}

Cows grazed high quality perennial ryegrass pasture under a restricted daily herbage allowance supplemented with three levels of concentrate $(0,4$ and $8 \mathrm{~kg})$. The supplementation of concentrate to a pasture-only diet increased animal production, by 
increasing total DMI, regardless of the concentrate level, and by increasing milk yield and ECM step-wise with increasing concentrate level. Total DMI increased when the pasture-only diet was supplemented with concentrate while $\mathrm{CH}_{4}$ emissions (g/d) were unchanged. Regardless, $\mathrm{CH}_{4}$ intensity (g/kg of milk yield) decreased linearly with increasing concentrate feeding level. Results from the rumen study failed to completely support the $\mathrm{CH}_{4}$ emission results. More research is needed to fully elucidate the role of rumen fermentation parameters as proxies for enteric $\mathrm{CH}_{4}$ emissions in grazing dairy cows. This study demonstrated that concentrate supplementation to high quality pasture diets has the potential to effectively reduce $\mathrm{CH}_{4}$ emissions per unit of milk yield from grazing cows during spring. Results from this study can be used to fine-tune the pasture-based dairy sector of the South African greenhouse gas inventory, and can also be useful for upcoming meta-analysis studies evaluating the effect of diet on enteric $\mathrm{CH}_{4}$ emissions in improving existing enteric $\mathrm{CH}_{4}$ prediction equations. Finally, the impact that concentrate supplementation could have on the total carbon footprint, on- and off-farm, as well as the effect on profitability at the farm scale should not be overlooked.

\section{Acknowledgements}

The authors wish to express their sincere gratitude to the Western Cape Agricultural Research Trust (Elsenburg, South Africa), Western Cape Department of Agriculture (Elsenburg, South Africa) and to the Department of Animal and Wildlife Sciences at the University of Pretoria (Pretoria, South Africa) for providing the funding and infrastructure. The milking team and farm aids at the Outeniqua Research Farm need special reference for their work ethics while executing the trial. The financial assistance of the National Research Foundation (NRF; Pretoria, South Africa) towards this research is hereby also acknowledged. 
Opinions expressed and conclusions arrived at, are those of the author and are not necessarily to be attributed to the NRF.

\section{References}

AgriLASA (Agri Laboratory Association of Southern Africa), 1998. Feed and plant analysis methods. AgriLASA, Pretoria, RSA.

Aguerre, M.J., Wattiaux, M.A., Powell, J.M., Broderick, G.A., Arndt, C., 2011. Effect of forage-toconcentrate ratio in dairy cow diets on emission of methane, carbon dioxide, and ammonia, lactation performance, and manure excretion. J. Dairy Sci. 94, 3081-3093.

AOAC (Association of Official Analytical Chemists), 2000. Official Methods of Analysis, 17th ed. AOAC, Gaithersburg, MD.

Bargo, F., Muller, L.D., Kolver, E.S., Delahoy, J.E., 2003. Invited review: Production and digestion of supplemented dairy cows on pasture. J. Dairy Sci. 86, 1-42.

Bargo, F., Muller, L.D., Varga, G.A., Delahoy, J.E., Cassidy, T.W., 2002. Ruminal digestion and fermentation of high producing dairy cows with three different feeding systems combining pasture and total mixed rations. J. Dairy Sci. 85, 2964-2973.

Berndt, A., Boland, T.M., Deighton, M.H., Gere, J.I., Grainger, C., Hegarty, R.S., Iwaasa, A.D., Koolaard, J.P., Lassey, K.R., Luo, D., Martin, R.J., Moate, P.J., Molano, G., Pinares-Patiño, C., Ribaux, B.E., Swainson, N.M., Waghorn, G.C., Williams, S.R.O., 2014. Guidelines for use of sulphur hexafluoride $\left(\mathrm{SF}_{6}\right)$ tracer technique to measure enteric methane emissions from ruminants. Lambert, M.G. (Ed.). New Zealand Agricultural Greenhouse Gas Research Centre, NZ.

Broderick, G.A., Kang, J.H., 1980. Automated simultaneous determination of ammonia and total amino acids in ruminal fluid and in vitro media. J. Dairy Sci. 63, 64-75.

Cabral, C.H.A., Paulino, M.F., Detmann, E., Filho, S.D.V., de Barros, L.V., Valente, E.E.L., Bauer, M.D., Cabral, C.E.A., 2014. Levels of supplementation for grazing beef heifers. AsianAustralas. J. Anim. Sci. 27, 806-817. 
Charmley, E., Williams, S.R.O., Moate, P.J., Hegarty, R.S., Herd, R.M., Oddy, V.H., Reyenga, P., Staunton, K.M., Anderson, A., Hannah, M.C., 2016. A universal equation to predict methane production of forage-fed cattle in Australia. Anim. Prod. Sci. 56, 169-180.

Cruywagen, C.W., 2006. Technical note: A method to facilitate the retrieval of polyester bags used in in sacco trials in ruminants. J. Dairy Sci. 89, 1028-1030.

de Souza, J., Batistel, F., Welter, K.C., Silva, M.M., Costa, D.F., Santos, F.A.P., 2015. Evaluation of external markers to estimate fecal excretion, intake and digestibility in dairy cows. Trop. Anim. Health Prod. 47, 265-268.

Deighton, M.H., Williams, S.R.O., Hannah, M.C., Eckard, R.J., Boland, T.M., Wales, W.J., Moate, P.J., 2014. A modified sulphur hexafluoride tracer technique enables accurate determination of enteric methane emissions from ruminants. Anim. Feed Sci. Technol. 197, 47-63.

Du Toit, C.J.L., Meissner, H.H., van Niekerk, W.A., 2013. Direct methane and nitrous oxide emissions of South African dairy and beef cattle. S. Afr. J. Anim. Sci. 43, 320-339.

Eckard, R.J., Grainger, C., de Klein, C.A.M., 2010. Options for the abatement of methane and nitrous oxide from ruminant production: A review. Livest. Sci. 130, 47-56.

Filípek, J., Dvořák, R., 2009. Determination of the volatile fatty acid content in the rumen liquid: comparison of gas chromatography and capillary isotachophoresis. Acta. Vet. Brno. 78, 627633.

Gaines, W.L., 1928. The energy basis of measuring milk yield in dairy cows. University of Illinois, Agric. Exp. Station, Bulletin 308.

Hristov, A.N., Oh, J., Firkins, J.L., Dijkstra, J., Kebreab, E., Waghorn, G., Makkar, H.P.S., Adesogan, A.T., Yang, W., Lee, C., Gerber, P.J., Henderson, B., Tricarico, J.M., 2013. SPECIAL TOPICS-Mitigation of methane and nitrous oxide emissions from animal operations: I. A review of enteric methane mitigation options. J. Anim. Sci. 91, 5045-5069.

Huhtanen, P., Hetta, M., 2012. Comparison of feed intake and milk production responses in continuous and change-over design dairy cow experiments. Livest. Sci. 143, 184-194.

IPCC (Intergovernmental Panel on Climate Change), 2006. 2006 IPCC Guidelines for National Greenhouse Gas Inventories. Prepared by the National Greenhouse Gas Inventories 
Programme. Eggleston, H.S., Buendia, L., Miwa, K., Ngara, T., Tanabe, K. (Eds). Institute for Global Environmental Strategies (IGES), Hayama, Kanagawa, Japan.

Jiao, H.P., Dale, A.J., Carson, A.F., Murray, S., Gordon, A.W., Ferris, C.P., 2014. Effect of concentrate feed level on methane emissions from grazing dairy cows. J. Dairy Sci. 97, 70437053.

Knapp, J.R., Laur, G.L., Vadas, P.A., Weiss, W.P., Tricarico, J.M., 2014. Invited review: Enteric methane in dairy cattle production: Quantifying the opportunities and impact of reducing emissions. J. Dairy Sci. 97, 3231-3261.

Krizsan, S.J., Rinne, M., Nyholm, L., Huhtanen, P., 2015. New recommendations for the ruminal in situ determination of indigestible neutral detergent fibre. Anim. Feed Sci. Technol. 205, 31-41.

Lovett, D.K., Stack, L.J., Lovell, S., Callan, J., Flynn, B., Hawkins, M., O’Mara, F.P., 2005. Manipulating enteric methane emissions and animal performance of late-lactation dairy cows through concentrate supplementation at pasture. J. Dairy Sci. 88, 2836-2842.

MAFF, 1984. Energy allowances and feeding systems for ruminants. Ministry of Agriculture, Fisheries and Food, London, HMSO.

Moe, P.W., Tyrrell, H.F., 1979. Methane production in dairy cows. J. Dairy Sci. 62, 1583-1586.

Muñoz, C., Hube, S., Morales, J.M., Yan, T., Ungerfeld, E.M., 2015. Effects of concentrate supplementation on enteric methane emissions and milk production of grazing dairy cows. Livest. Sci. 175, 37-46.

Myers, W.D., Ludden, P.A., Nayigihugu, V., Hess, B.W., 2004. Technical note: A procedure for the preparation and quantitative analysis of samples for titanium dioxide. J. Anim. Sci. 82, 179183.

Myhre, G., Shindell, D., Bréon, F.M., Collins, W., Fuglestvedt, J., Huang, J., Koch, D., Lamarque, J.F., Lee, D., Mendoza, B., Nakajima, T., Robock, A., Stephens, G., Takemura, T., Zhang, H., 2013. Anthropogenic and Natural Radiative Forcing, in Stocker, T.F., Qin, D., Plattner, G.K., Tignor, M., Allen, S.K., Boschung, J., Nauels, A., Xia, Y., Bex, V., Midgley, P.M. (Eds.), Climate Change 2013: The Physical Science Basis, contribution of Working Group I to the 
Fifth Assessment Report of the Intergovernmental Panel on Climate Change. Cambridge University Press, Cambridge, UK, and New York, USA, pp. 659-740.

Negussie, E., de Haas, Y., Dehareng, F., Dewhurst, R.J., Dijkstra, J., Gengler, N., Morgavi, D.P., Soyeurt, H., van Gastelen, S., Biscarini, F., 2017. Invited review: Large-scale indirect measurements for enteric methane emissions in dairy cattle: A review of proxies and their potential for use in management and breeding decisions. J. Dairy Sci. 100, 2433-2453.

NRC (National Research Council), 2001. Nutrient Requirements of Dairy Cattle: Seventh revised edition. Subcommittee on Dairy Cattle Nutrition, Committee on Animal Nutrition and Board on Agriculture and Natural Resources. National Academy Press, Washington, DC.

O’Neill, B.F., Deighton, M.H., O’Loughlin, B.M., Mulligan, F.J., Boland, T.M., O’Donovan, M., Lewis, E., 2011. Effects of a perennial ryegrass diet or total mixed ration diet offered to springcalving Holstein-Friesian dairy cows on methane emissions, dry matter intake, and milk production. J. Dairy Sci. 94, 1941-1951.

Payne, R.W., Murray, D., Harding, S., Baird, D., Soutar, D., 2014. GenStat for Windows, 17th ed. VSN International, Hemel Hempstead, Hertfordshire, UK.

Pérez-Prieto, L.A., Delagarde, R., 2012. Meta-analysis of the effect of pregrazing pasture mass on pasture intake, milk production, and grazing behavior of dairy cows strip-grazing temperate grasslands. J. Dairy Sci. 95, 5317-5330.

Peyraud, J.L., Delagarde, R., 2013. Managing variations in dairy cow nutrient supply under grazing. Anim. 7, 57-67. http://dx.doi.org/10.1017/S1751731111002394.

Pinares-Patiño, C.S., Molano, G., Smith, A., Clark, H., 2008. Methane emissions from dairy cattle divergently selected for bloat susceptibility. Aust. J. Exp. Agric. 48, 234-239.

Robertson, J.B., van Soest, P.J., 1981. The Detergent System of Analysis and Its Application to Human Foods. In: James, W.P.T., Theander, O. (Eds.), Basic and clinical nutrition vol 3. The analysis of dietary fibre in food. Dekker, NY, pp. 158-276.

Roseler, D.K., Ferguson, J.D., Sniffen, C.J., Herrema, J., 1993. Dietary protein degradability effects on plasma and milk urea nitrogen and milk nonprotein nitrogen in Holstein cows. J. Dairy Sci. 76, 525-534. 
Snedecor, G.W., Cochran, W.G., 1980. Statistical methods, 7th ed. Iowa State University Press, pp. 507.

Stockdale, C.R., 2000. Levels of pasture substitution when concentrates are fed to grazing dairy cows in northern Victoria. Aust. J. Exp. Agric. 40, 913-921.

Swanepoel, P.A., Botha, P.R., Du Preez, C.C., Snyman, H.A., 2013. Physical quality of a podzolic soil following 19 years of irrigated minimum-till kikuyu-ryegrass pasture. Soil Tillage Res. $133,10-15$.

Tilley, J.M., Terry, R.A., 1963. A two-stage technique for the in vitro digestion of forage crops. J. Br. Grassl. Soc. 18, 104-111.

Tyrrell, H.F., Moe, P.W., 1972. Net energy value for lactation of a high and low concentrate ration containing corn silage. J. Dairy Sci. 55, 1106-1112.

Tyrrell, H.F., Reid, J.T., 1965. Prediction of the energy value of cow's milk. J. Dairy Sci. 48, 12151223.

van der Colf, J., Botha, P.R., Meeske, R., Truter, W.F., 2015. Seasonal dry matter production, botanical composition and forage quality of kikuyu over-sown with annual or perennial ryegrass. Afr. J. Range Forage Sci. 33, 133-142.

van Kessel, J.A.S., Russell, J.B., 1996. The effect of $\mathrm{pH}$ on ruminal methanogenesis. FEMS Microbiol. Ecol. 20, 205-210.

van Nevel, C.J., Demeyer, D.I., 1996. Control of rumen methanogenesis. Environ. Monit. Assess. 42, 73-97.

van Wyngaard, J.D.V., Meeske, R., Erasmus, L.J., 2018. Technical note: A simple back-mounted harness for grazing dairy cows to facilitate the sulfur hexafluoride tracer gas technique. J. Dairy Sci. 101, 2655-2658.

Wildman, E.E., Jones, G.M., Wagner, P.E., Boman, R.L., Troutt, H.F., Jr., Lesch, T.N., 1982. A dairy cow body condition scoring system and its relationship to selected production characteristics. J. Dairy Sci. 65, 495-501. 
Williams, S.R.O., Moate, P.J., Hannah, M.C., Ribaux, B.E., Wales, W.J., Eckard, R.J., 2011. Background matters with the $\mathrm{SF}_{6}$ tracer method for estimating enteric methane emissions from dairy cows: A critical evaluation of the $\mathrm{SF}_{6}$ procedure. Anim. Feed Sci. Technol. 170, 265-276.

Yan, T., Mayne, C.S., Gordon, F.G., Porter, M.G., Agnew, R.E., Patterson, D.C., Ferris, C.P., Kilpatrick, D.J., 2010. Mitigation of enteric methane emissions through improving efficiency of energy utilization and productivity in lactation dairy cows. J. Dairy Sci. 93, 2630-2638.

Young, F., Ferris, C.F., 2011. Effect of concentrate feed level on methane production by grazing dairy cows, in: Proc. Agric. Res. Forum 2011. Tullamore, Co. Offaly, Ireland. Teagasc, Dublin, Ireland, page 58. 